\title{
A GRAPHIC CHART METHOD OF STUDYING AND TEACHING 'IHE PRINCIPLES OF INFANT FEEDING
}

\author{
WITII SPECTAL REFERENCE TO THE IMPORTANCE OF THE ENERGY LINE * \\ DAVID MURRAY COWIE, M.D. \\ Clinical Professor of Pediatrics and Internal Medicine, University of Michigan \\ ANN ARBOR, MICH.
}

I wish to present a method which I have been using with considerable satisfaction in teaching the principles of infantile nutrition, a graphic chart method which supplements previous instruction. The chart is simple, easily understood and records the weight variations, the energy line, which indicates how much food the infant needs, the food blocks, which show how much food has been given and retained, and presents a graphic representation of the number and character of the stools. Various other happenings of the day can also be indicated. Thus the chart forms a complete summary of the case for each day. A few explanations will be necessary.

The chart is arranged for daily records for eight weeks with room for a gain of 4 pounds. The spaces between the ordinates represent days, each abscissa represents 2 ounces, between the abscissæ 1 ounce. A gram column parallels the pound column. The calorie column may be started with each abscissa representing either 10 or 20 calories and is usually begun on an even number approximately corresponding to the caloric requirement 1 pound below the entrance weight, in order to allow for weight drops, etc.

Plotting the Energy Line.-This line is constructed from the infant's weight, 45 calories per pound during the first six months of life, gradually declining to 40 or 36 calories during the latter months of the first year.

Plotting the Food Line.-The caloric value of the food is calculated in the usual way. After the student has become thoroughly familiar with this computation he is given a table of the caloric values of one ounce of the various foods used in the ward. (Table 1.) The amount of food in calories ingested and retained is charted. (See Chart 9.)

Charting the Stools.-A series of symbols are used. These may be varied as one desires. The usual ones employed and which the nurses and

\footnotetext{
*From the Department of Pediatrics, University of Michigan.

* Read by title at the rneeting of the American Pediatric Society, Hot Springs, Va., May, 1912.
} 
students use with readiness are the ones indicated in the stool column. Such combinations of these symbols as the following may be made:

The first symbol indicates a hard stool with curds; alkaline in reaction; the second a liquid stool with curds, mucus and blood; acid reaction; the third an extra sign for any other type of stool.
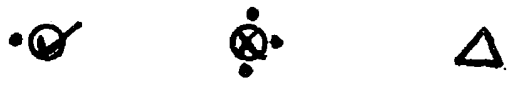

The chart when completed for the day is a representation of the so-called percentage and caloric methods. Both of which must figure in

Table 1.-The Caloric Value of ONe Ounce of the Vartous Modrfied Milk Formula and Foods Used in Palmer Memorial Ward

\begin{tabular}{|c|c|c|c|c|c|c|}
\hline \multicolumn{3}{|c|}{ Formula, Per Cent. } & \multicolumn{4}{|c|}{ - Calories From } \\
\hline $\mathrm{F}$ & $\mathbf{S}$ & $\mathbf{P}$ & Fat & Sugar & Protein & Total \\
\hline $\begin{array}{l}1 \\
1.5 \\
1.5 \\
1.5 \\
1.5 \\
1.5 \\
2 \\
2 \\
2 \\
2 \\
2 \\
2.5 \\
2.5 \\
2.5 \\
3 \\
3 \\
3 \\
3 \\
3 \\
3 \\
3 \\
3 \\
3.5 \\
4\end{array}$ & $\begin{array}{l}\mathbf{5} \\
\mathbf{5} \\
\mathbf{5} \\
\mathbf{5} \\
\mathbf{5} \\
\mathbf{5} \\
\mathbf{5} \\
\mathbf{5} \\
\mathbf{5} \\
\mathbf{5} \\
\mathbf{5} \\
\mathbf{5} \\
\mathbf{5} \\
\mathbf{5} \\
\mathbf{5} \\
\mathbf{5} \\
\mathbf{5} \\
\mathbf{6} \\
\mathbf{6} \\
\mathbf{6} \\
\mathbf{5} \\
\mathbf{5} \\
\mathbf{5} \\
\mathbf{5}\end{array}$ & $\begin{array}{l}0.5 \\
0.5 \\
0.75 \\
1 \\
1.5 \\
2 \\
0.5 \\
0.75 \\
1 \\
1.5 \\
2 \\
1 \\
1.5 \\
2 \\
1 \\
1.5 \\
2 \\
1 \\
1.5 \\
2 \\
2.5 \\
3 \\
3 \\
3\end{array}$ & $\begin{array}{r}2.79 \\
4.18 \\
4.18 \\
4.18 \\
4.18 \\
4.18 \\
5.58 \\
5.58 \\
5.58 \\
\mathbf{5 . 5 8} \\
\mathbf{5 . 5 8} \\
6.97 \\
6.97 \\
6.97 \\
\mathbf{8 . 3 7} \\
\mathbf{8 . 3 7} \\
\mathbf{8 . 3 7} \\
\mathbf{8 . 3 7} \\
\mathbf{8 . 3 7} \\
\mathbf{8 . 3 7} \\
\mathbf{8 . 3 7} \\
\mathbf{8 . 3 7} \\
\mathbf{9 . 7 6} \\
11.16\end{array}$ & $\begin{array}{l}6.15 \\
6.15 \\
6.15 \\
6.15 \\
6.15 \\
6.15 \\
6.15 \\
6.15 \\
6.15 \\
6.15 \\
6.15 \\
6.15 \\
6.15 \\
6.15 \\
6.15 \\
6.15 \\
6.15 \\
7.38 \\
7.38 \\
7.38 \\
6.15 \\
6.15 \\
6.15 \\
6.15\end{array}$ & $\begin{array}{l}0.61 \\
0.61 \\
0.922 \\
1.23 \\
1.845 \\
2.46 \\
0.615 \\
0.922 \\
1.23 \\
1.84 \\
2.46 \\
1.23 \\
1.84 \\
2.46 \\
1.23 \\
1.84 \\
2.46 \\
1.23 \\
1.84 \\
2.46 \\
3.07 \\
3.69 \\
3.69 \\
3.69\end{array}$ & $\begin{array}{c}9.55 \\
10.95 \\
11.235 \\
11.56 \\
12.17 \\
12.79 \\
12.34 \\
12.05 \\
12.96 \\
13.57 \\
14.19 \\
14.35 \\
14.96 \\
15.58 \\
15.75 \\
16.36 \\
16.98 \\
16.98 \\
17.59 \\
18.21 \\
17.59 \\
18.21 \\
19.60 \\
21.01\end{array}$ \\
\hline $\begin{array}{l}\text { Wh } \\
\text { Mil } \\
\text { Cor } \\
\text { Wo } \\
\text { Ski } \\
\text { Wh } \\
\text { But } \\
\text { Pre } \\
\text { Eiv } \\
\text { Kel } \\
\text { Oat } \\
\text { Bar }\end{array}$ & $\begin{array}{l}\text { ilk } \\
\text { sar } \\
\text { ik } \\
\text { mi } \\
\text { lk } \\
\text { lk, } \\
\text { ted } \\
\text { ilk, } \\
\text { nalt } \\
\text { s, dr } \\
\text { our, }\end{array}$ & $\begin{array}{l}\ldots \ldots \\
\ldots \ldots \\
\ldots \ldots \\
\ldots \ldots \\
\ldots \ldots \\
\text { simat } \\
\text { a, apy } \\
\text { oxima } \\
\text { appr } \\
\text { proxir } \\
\text { apprc }\end{array}$ & $\begin{array}{l}\ldots \ldots \\
\ldots \ldots \\
\ldots \ldots \\
\ldots \ldots \\
\ldots \ldots \\
\ldots \ldots \\
\ldots \ldots \\
\text { ately } \\
\ldots \ldots \\
\text { tely } \\
\ldots \\
\text { ely } \ldots\end{array}$ & 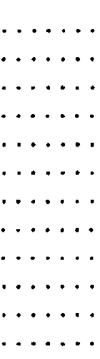 & 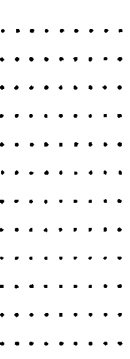 & $\begin{array}{c}21.01 \\
13.00 \\
21.01 \\
20.5 \\
12.0 \\
6.0 \\
5.0 \\
15.0 \\
11.0^{*} \\
24.0 \\
116.0 \\
103.0\end{array}$ \\
\hline
\end{tabular}

*The caloric value of Eixeissmilch varies 11 and 15 calories per ounce, depending on the percentage of fat in the whole milk and the quality of the buttermilk. 
the proper feeding of an infant. There has been so much said about the advantages of one method over the other that I usually begin my work in infant feeding by illustrating the foundation that has been laid in this country by American masters whose names are so familiar to all of us. America has been in no way behind in the development of a knowledge of infantile nutrition. Chart 1 illustrates how closely we have come to the needs of the body as attested by the energy line. I have plotted the weight-curve of a normal bottle-fed baby (taken from Holt) and the maximum amount of food in calories used as a routine by those who follow the percentage feeding scheme. (Arranged from Holt's table.) The gain in weight is seen to follow feeding above the energy line. A chart plotted with the optimum amount of food generally prescribed would bring the food line from 20 to $\% 0$ calories above the energy line. It will be seen that infants fed by this scheme have not been underfed, and it should also be stated that the proportion of each food constituent has been carefully adjusted.

'Table 2.-Protein Requirements per Kilo of Body-Weight

\begin{tabular}{|c|c|c|c|}
\hline \multirow{2}{*}{ Age } & \multicolumn{3}{|c|}{ Required Grams of Protein per } \\
\hline & Kg.Body-Wght & Pound & Ounce \\
\hline $\begin{array}{l}2 \text { Weeks } \ldots \ldots \ldots \\
2 \text { Weeks } \ldots \ldots \ldots \ldots \\
3 \ldots \ldots \ldots \ldots \ldots \ldots \\
+\ldots \ldots \ldots \ldots \ldots \ldots \\
2 \text { to } 12 \text { montlis } \ldots\end{array}$ & $\begin{array}{l}1.5 \\
1.5 \\
2.0 \\
2.5 \\
2.5 \cdot 3.3\end{array}$ & $\begin{array}{l}0.68 \\
0.68 \\
0.90 \\
1.10 \\
1.10-1.5\end{array}$ & $\begin{array}{l}0.0425 \\
0.0425 \\
0.056 \\
0.0687 \\
0.093\end{array}$ \\
\hline
\end{tabular}

The most important point to impress on the student is the basic protein requirement of the body. By a previous special study of metabolism as related to infantile growth and development, the student has become acquainted with this basic or minimum protein requirement. $\mathrm{He}$ is now taught how to put this into practice by means of the chart. Chart 2 illustrates a simple case. By use of the accompanying table (2) he determines the number of grams of protein required and from this it becomes a simple matter to determine the percentage. He then chooses 5 or 6 per cent. sugar as a constant and makes up the balance of his calories from fat. In the present case the infant has been started on a 2-6-1.5 mixture. The protein has been gradually increased to 1.75 per cent. or 2 per cent. and the fat by steps from 2 to 3 per cent. As the protein is the tissue builder it is placed as the foundation stone in the food block. The daily quantity of food is readily determined as follows: 
Table 3.-Chabt Making Exercise, Baby A., Case 1

\begin{tabular}{|c|c|c|c|c|c|c|}
\hline \multirow{2}{*}{\multicolumn{2}{|c|}{ Date }} & \multicolumn{2}{|c|}{$\begin{array}{l}\text { Weights from } \\
\text { Birth }\end{array}$} & \multicolumn{2}{|c|}{ Food from Birth } & \multirow{2}{*}{ Stools from Birth } \\
\hline & & Pounds & Ounces & Formula & Ounces & \\
\hline \multirow{30}{*}{ June } & 1 & 7 & 10 & $\ldots \ldots \ldots$ & $\ldots$ & 2 normal \\
\hline & 2 & . & $\ldots$ & $\ldots \ldots \ldots \ldots$ & .. & 2 \\
\hline & 3 & 7 & 8 & $\ldots \ldots \ldots$ & . & 3 \\
\hline & 4 & . & $\ldots$ & $6 \%$ sugar whey & 10 & 3 \\
\hline & 5 & $\because$ & $\cdots$ & $\ldots \ldots \ldots$ & .. & 4 \\
\hline & 6 & 7 & 5 & $\ldots \ldots \ldots$ & .. & 3 \\
\hline & 7 & . & $\ldots$ & $11 / 2-5-1 / 2$ & 20 & 3 \\
\hline & 8 & $\because$ & $\cdots$ & $\ldots \ldots \ldots$ & $\ldots$ & 1 normal, 1 curd \\
\hline & 9 & 7 & 8 & $\ldots \ldots \ldots$ & $\cdots$ & 2 normal \\
\hline & 10 & $\cdots$ & & $\ldots \ldots \ldots$ & .. & 3 \\
\hline & 11 & 7 & 10 & $\ldots \ldots \ldots$ & $\cdots$ & 2 \\
\hline & 12 & . & $\ldots$ & $\ldots \ldots \ldots$ & . & 2 \\
\hline & 13 & 7 & 11 & $\ldots \ldots \ldots \ldots$ & $\ldots$ & $\mathbf{3}$ \\
\hline & 14 & . & ... & $2 \cdot 5 \cdot 3 / 4$ & 30 & 3 \\
\hline & 15 & . & $\ldots$ & $\ldots \ldots \ldots$ & . & $\mathbf{3}$ \\
\hline & 16 & 7 & 14 & $\ldots \ldots \ldots$ & . & 2 normal, 1 with curds \\
\hline & 17 & $\cdots$ & $\cdots$ & $\ldots \ldots \ldots$ & $\cdots$ & 3 normal \\
\hline & 18 & 8 & $\cdots$ & $\ldots \ldots \ldots$ & . & 3 \\
\hline & 19 & . & $\therefore$ & $\ldots \ldots \ldots$ & $\cdots$ & 2 \\
\hline & 20 & 8 & 4 & $\ldots \ldots \ldots$ & . & 4 \\
\hline & 21 & . & $\ldots$ & $\ldots \ldots \ldots$ & . & $\mathbf{2}$ \\
\hline & 22 & . & $\ldots$ & $\ldots \ldots \ldots$ & . & 2 \\
\hline & 23 & . & $\ldots$ & $\ldots \ldots \ldots \ldots$ & $\cdots$ & 2 \\
\hline & 24 & 8 & 6 & $2-5-1$ & 30 & 2 \\
\hline & 25 & .. & $\cdots$ & $\ldots \ldots \ldots$ & .. & 2 \\
\hline & 26 & . & $\ldots$ & $\ldots \ldots \ldots$ & . & $\overline{2}$ \\
\hline & 27 & 8 & 10 & $\ldots \ldots \ldots$ & . & 3 normal, 1 with curds \\
\hline & 28 & . & $\cdots$ & $\ldots \ldots \ldots$ & $\cdots$ & 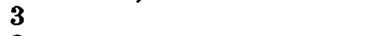 \\
\hline & 29 & $\cdots$ & $\ldots$ & $\ldots \ldots \ldots \ldots$ & . & 2 \\
\hline & 30 & $\cdots$ & $\cdots$ & $\ldots \ldots \ldots$ & . & 2 \\
\hline \multirow[t]{26}{*}{ July } & 1 & 8 & 14 & $\ldots \ldots \ldots$ & . & 2 \\
\hline & 2 & $\cdots$ & $\ldots$ & $\ldots \ldots \ldots$ & .. & 2 \\
\hline & $\mathbf{3}$ & . & $\cdots$ & $\ldots \ldots \ldots$ & . & 2 \\
\hline & 4 & 8 & 14 & $\cdots \ddot{m} \cdots$ & & 1 \\
\hline & 5 & $\cdots$ & $\cdots$ & $21 / 2-6-1$ & 31 & 1 \\
\hline & 6 & . & $\cdots$ & $\ldots \ldots \ldots$ & . & 3 normal, 3 with curds \\
\hline & 7 & 8 & 14 & $\ldots \ldots \ldots$ & . & 2 normal, 1 liquid curds \\
\hline & 8 & . & $\cdots$ & $\ldots \ldots \ldots$ & $\cdots$ & 3 with curds \\
\hline & 9 & . & $\cdots$ & $\ldots \ldots \ldots$ & . & 2 curd, 1 liquid, with curds \\
\hline & 10 & 8 & 12 & $\ldots \ldots \ldots$ & . & $2 \quad 4$ \\
\hline & 11 & . & $\ldots$ & $\ldots \ldots \ldots$ & $\therefore$ & 6 liquid with curds \\
\hline & 12 & 8 & 8 & $\ldots \ldots \ldots$ & 27 & 4 \\
\hline & 13 & .. & $\ldots$ & $\ldots \ldots \ldots$ & $\cdots$ & 3 \\
\hline & 14 & . & $\cdots$ & $\ldots \ldots \ldots$ & . & 2 with curds, 1 normal \\
\hline & 15 & 8 & 10 & $\ldots \ldots \ldots$ & .. & 3 normal \\
\hline & 16 & . & ... & $\ldots \ldots \ldots$ & . & 2 \\
\hline & 17 & . & $\ldots$ & $\ldots \ldots \ldots$ & $\ldots$ & 2 \\
\hline & 18 & 9 & 2 & $\ldots \ldots \ldots$ & 28 & 3 \\
\hline & 19 & . & $\ldots$ & $\ldots \ldots \ldots$ & . & 3 \\
\hline & 20 & . & $\ldots$ & $\ldots \ldots \ldots$ & . & 2 \\
\hline & 21 & 9 & 6 & $\ldots \ldots \ldots$ & . & 2 \\
\hline & 22 & . & $\ldots$ & $\ldots \ldots \ldots$ & $\ldots$ & 3 \\
\hline & 23 & $\ldots$ & $\ldots$ & $\ldots \ldots \ldots$ & 30 & 3 \\
\hline & 24 & 9 & 10 & $\ldots \ldots \ldots$ & . & 2 \\
\hline & 25 & $\cdots$ & $\cdots$ & $\ldots \ldots \ldots$ & .. & 2 \\
\hline & 26 & . & $\ldots$ & $\ldots \ldots \ldots$ & . & 2 \\
\hline
\end{tabular}


Table 4.-Chart Making Exercise, Baby B., Case 2

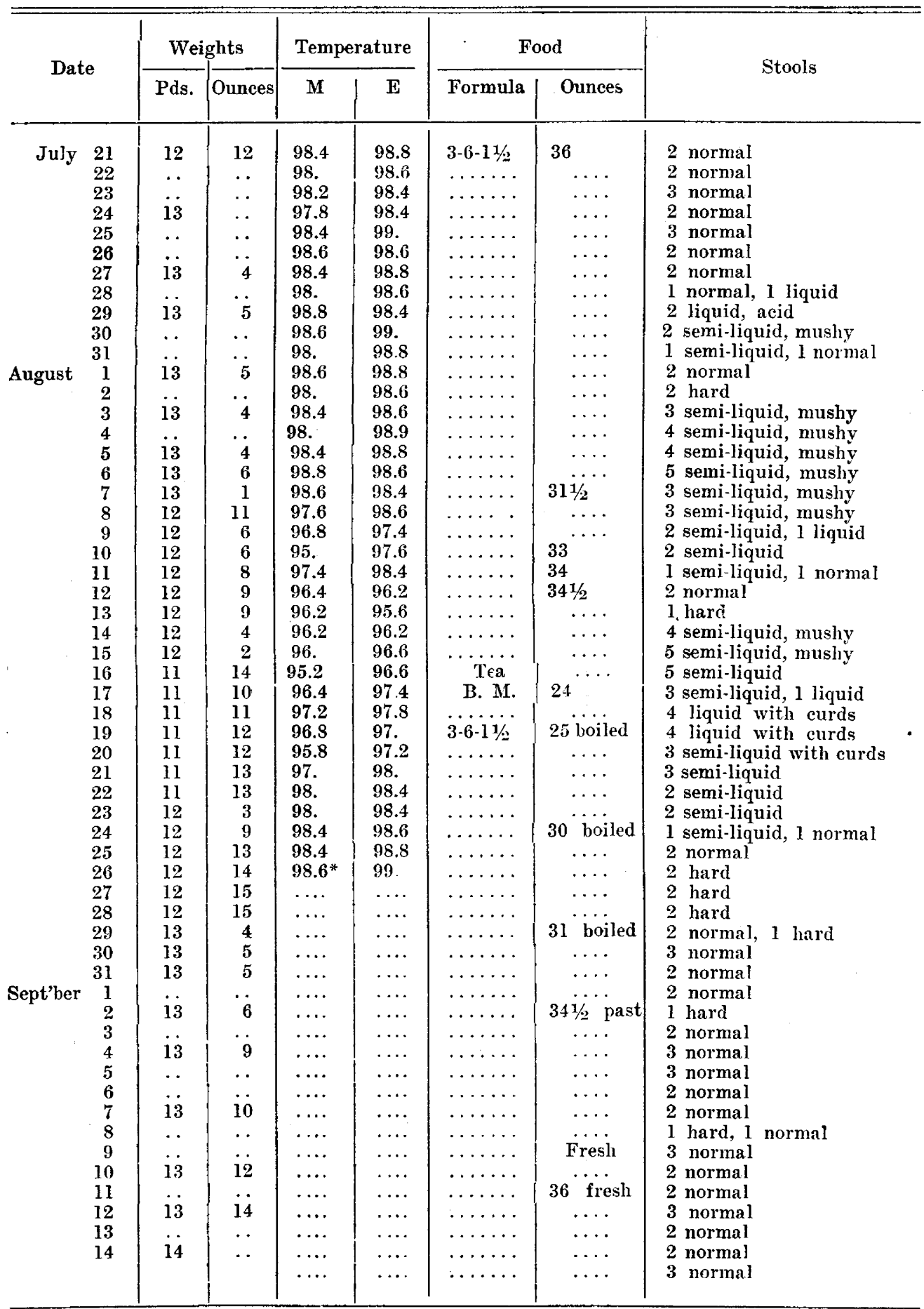

*Temperature normal thereafter. B. M. = Buttermilk. 


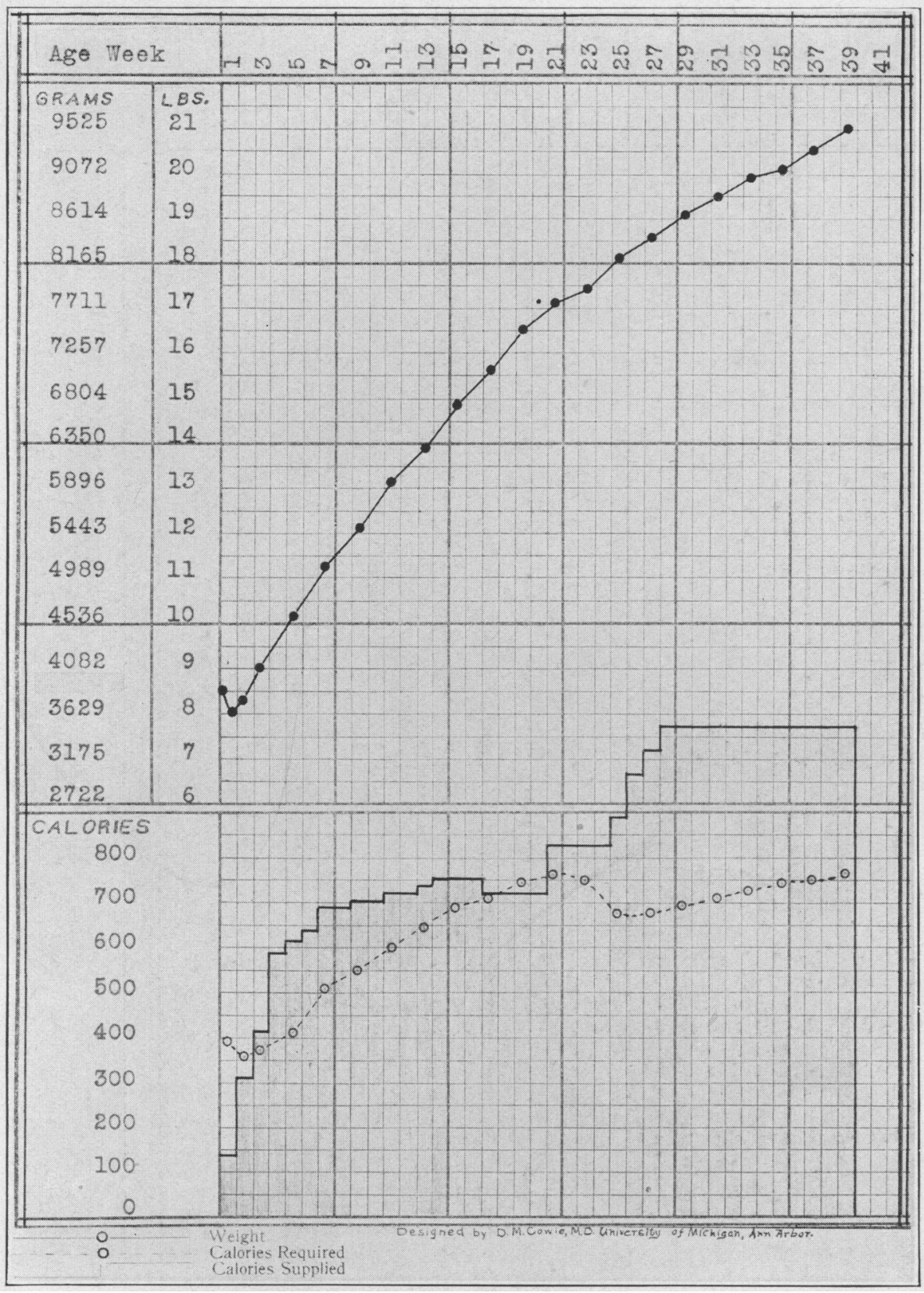

Chart 1.-This chart shows the average weight curve of a normal bottie fed infant, the energy line (calories of food required), and the amount of food (in calories) supplied by the maximum percentage formulæ quite generally employed by pediatricians in the United States. The chart further shows how correctly American children have been fed by the percentage method without reference to the "caloric method." 


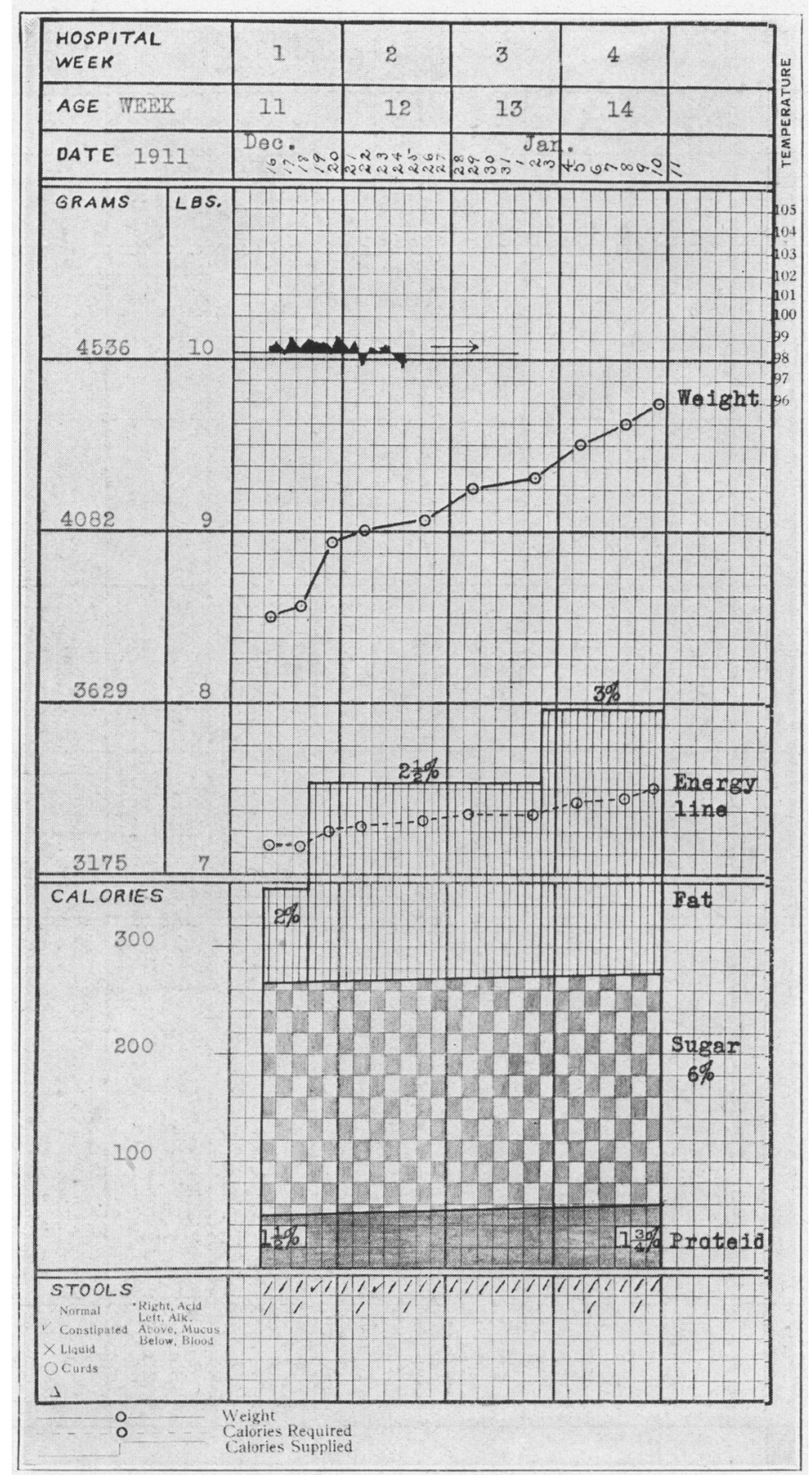

Chart 2.-Illustrating the minimum proteid requirement and the number of calories that must be furnished by sugar and fat to protect the proteid in its work of tissue building. 


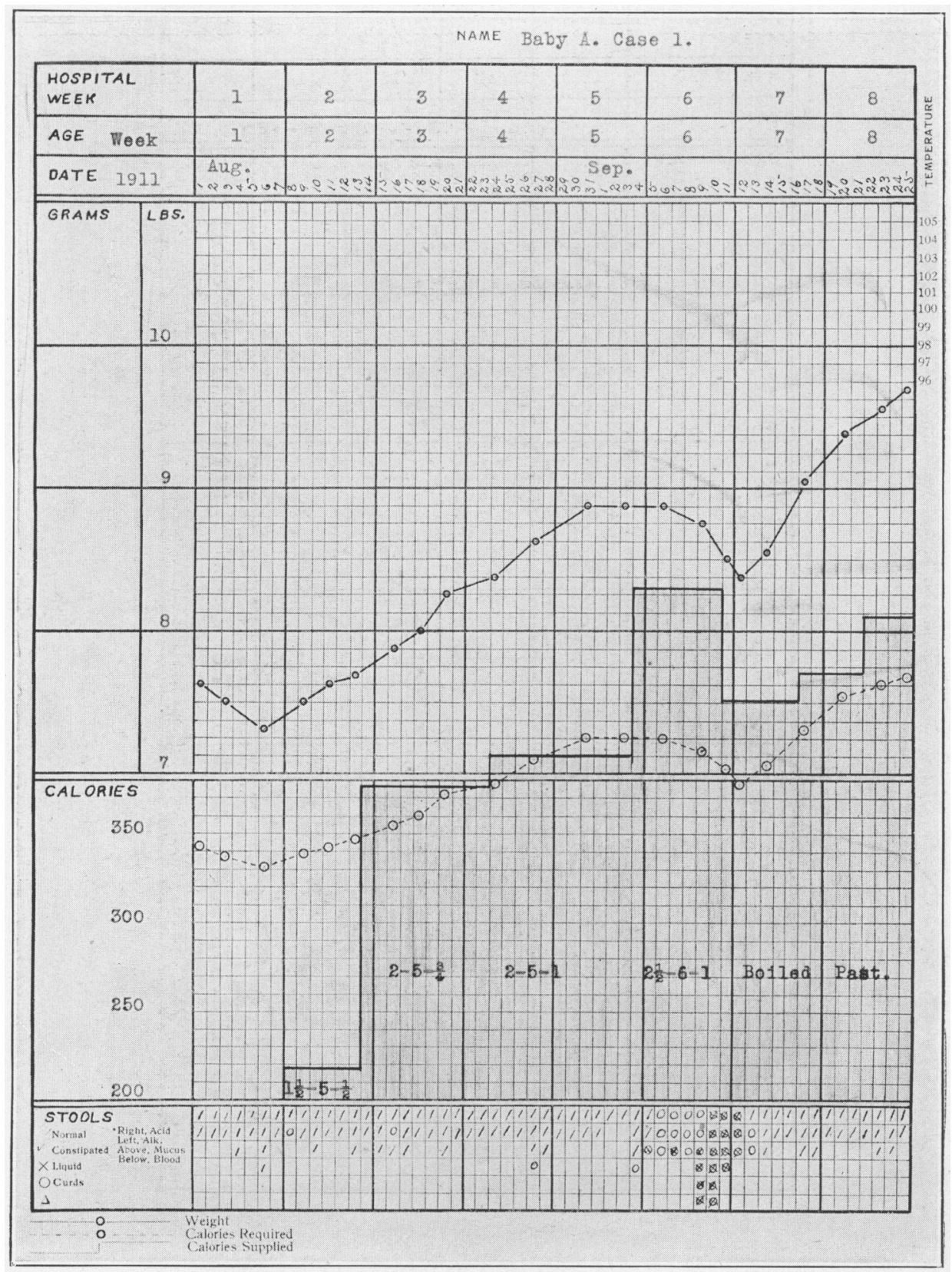

Chart 3.-11/2-5-1/2 ete. $=11 / 2$ per cent. fat, 5 per cent. sugar, $1 / 2$ per cent. proteid. 


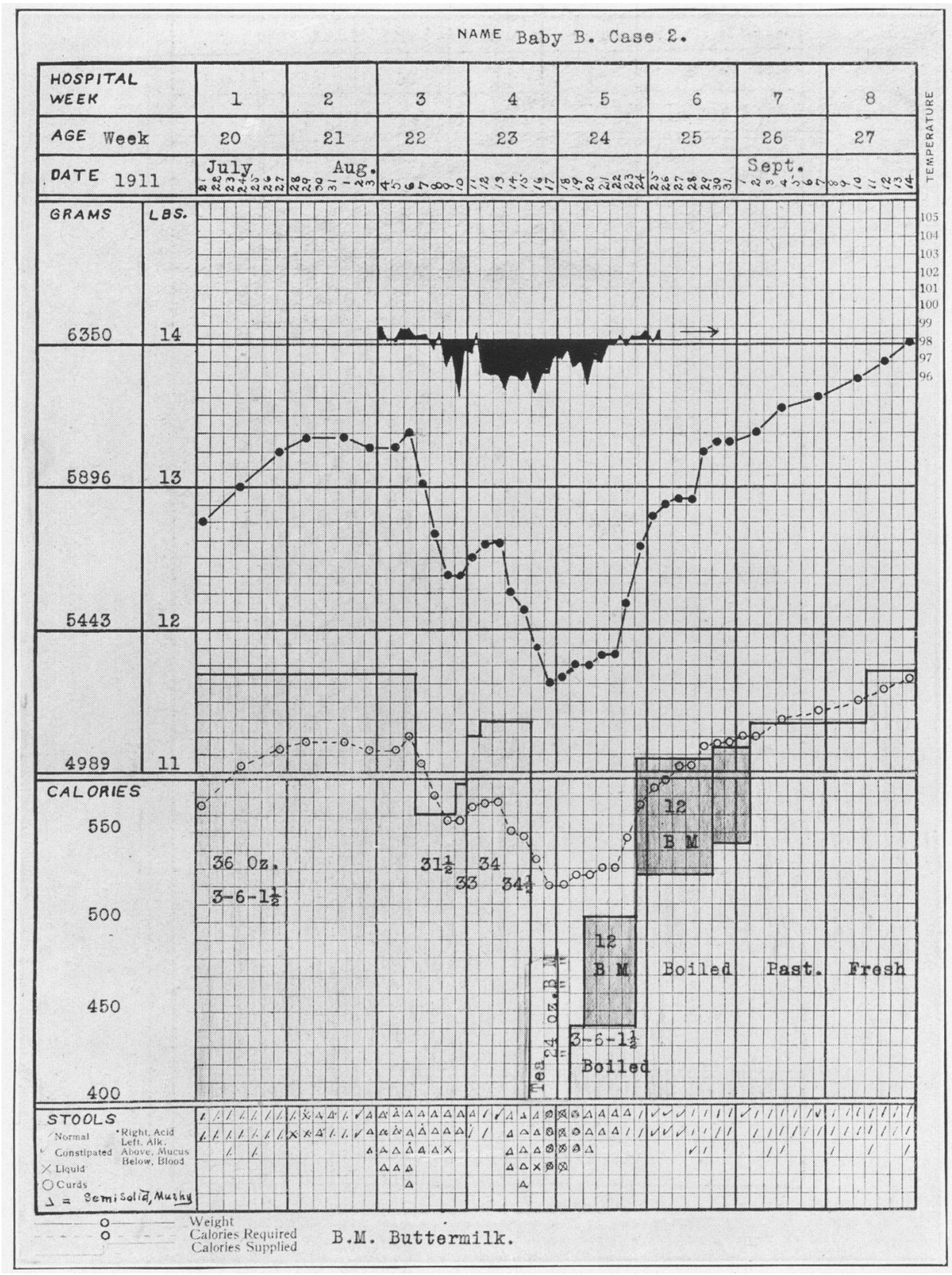

Chart 4. 


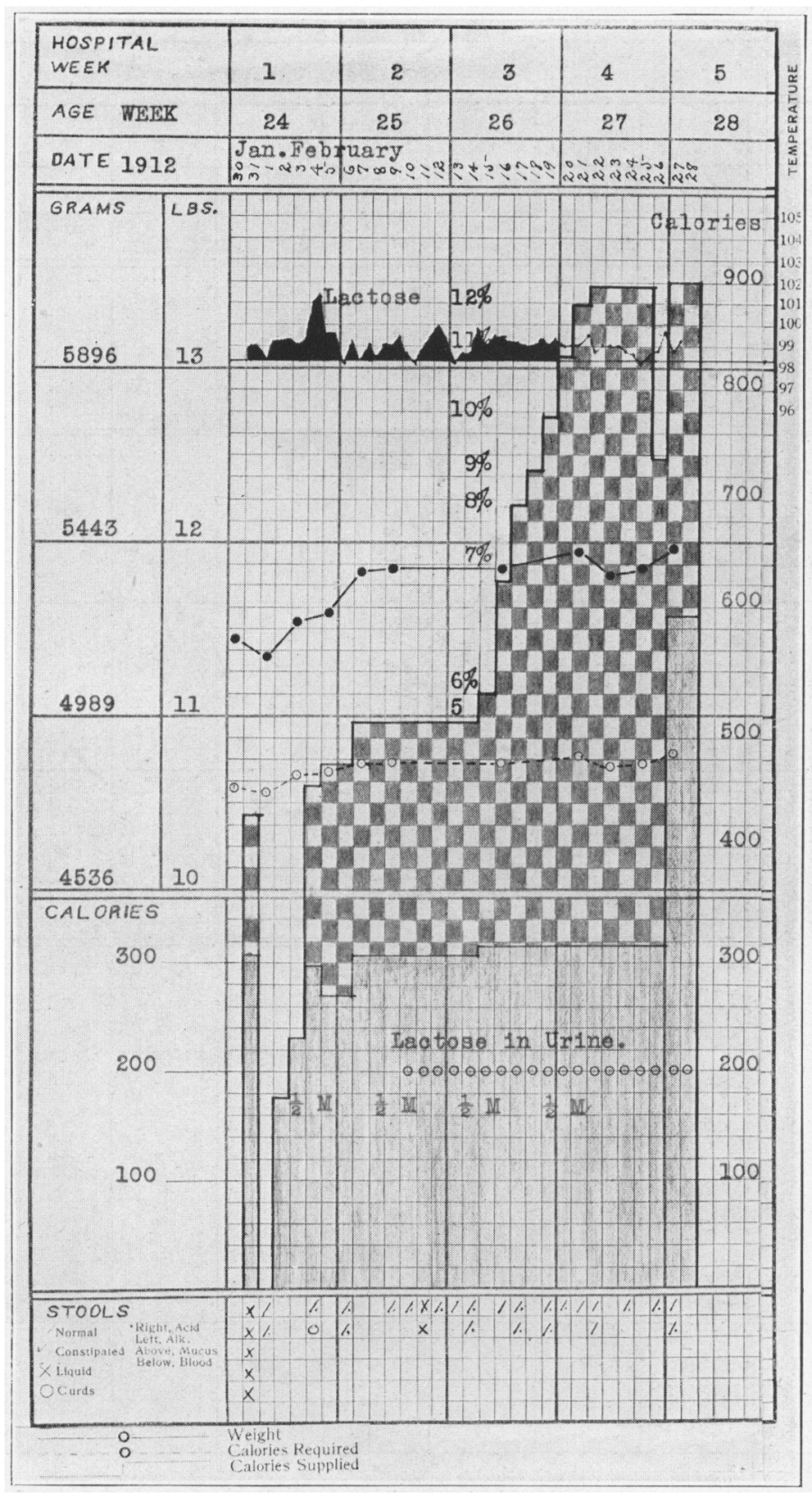

Chart 5.-Illustrating high sugar tolerance; $1 / 2 \mathrm{M}=$ half milk. The checkered portion shows amount of lactose added to the $1 / 2 \mathrm{M}$. 


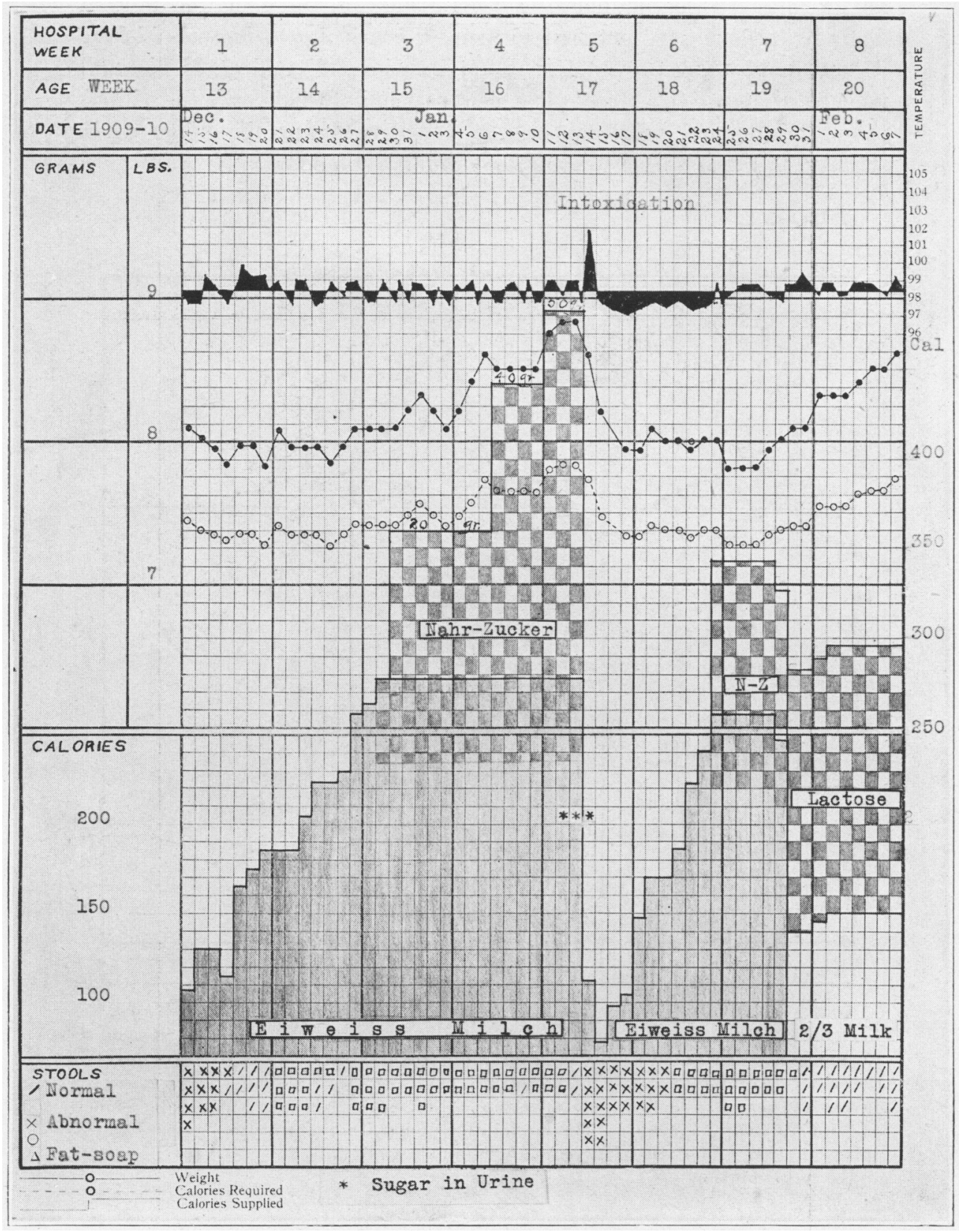

Chart 6.-Illustrating low sugar tolerance and resulting slight intoxication. The checkered portion below the Eiveissmilch line gives the approximate amount of sugar supplied in this food, above the line the amount of sugar added. The caloric value of the Eiweissmilch was doubtless higher than here estimated. Adopted from Finkelstein and Meyer. See text. 
In the present case, one ounce of 2-6-1.5 mixture has a caloric value of 14.8 ; 385 calories are required to bring the food up to the energy line. This number divided by 14.8 gives approximately 26 ounces, as the total amount of food. The food for a new patient is usually started a little below the line and later is pushed, as a routine, 30 or 40 calories above the line, to the approximate point of optimum tolerance.

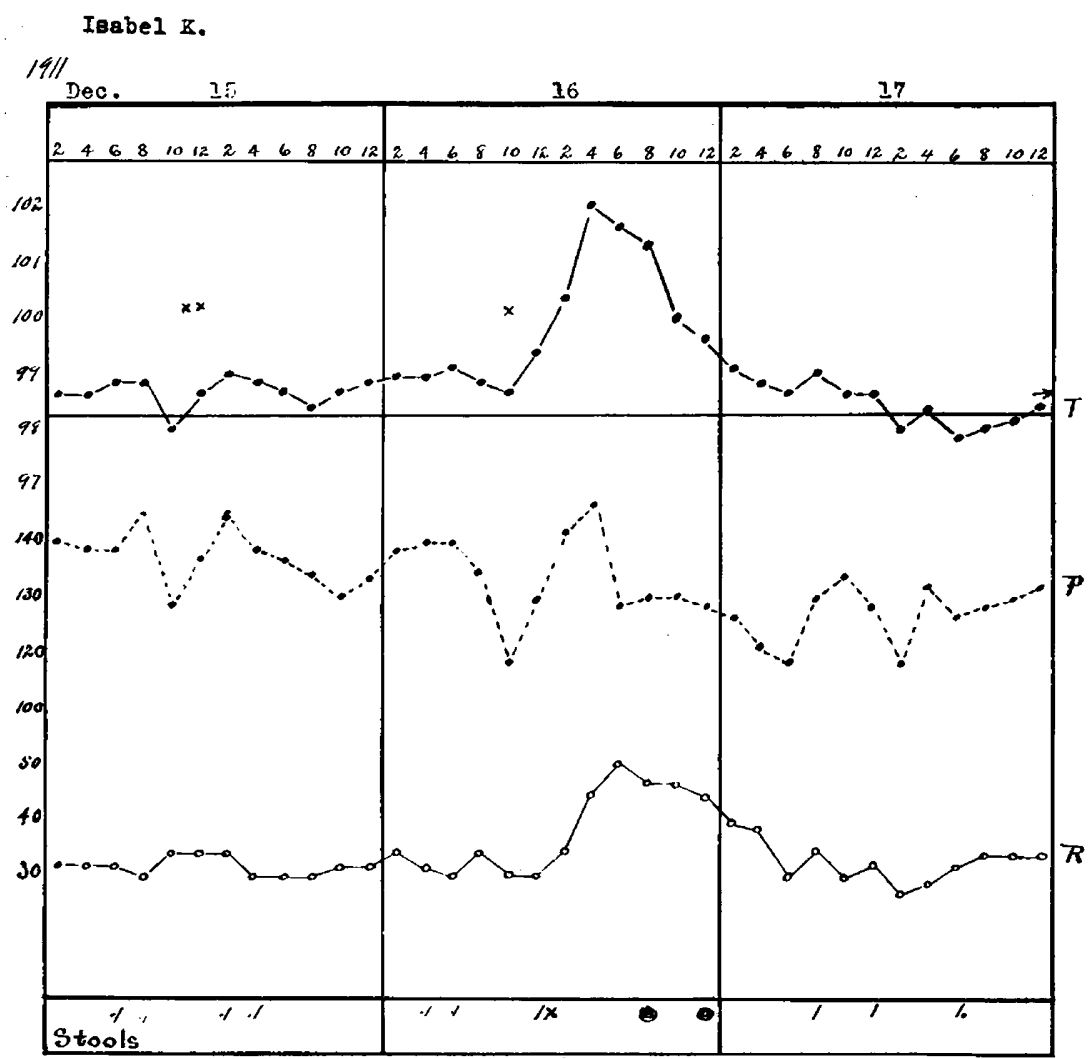

Chart 7.-Temperature, pulse and respiration curves in the case of Isabel $K$, a girl-baby, 10 weeks old, with normal digestion and normal stools. December 15 points nrarked $\mathrm{xx} 50$ grams of 1 per cent. $\mathrm{NaCl}$ solution were given by gavage, December 16 at point $\times 100$ grams of a 4 per cent. $\mathrm{NaCl}$ solution were given by gavage. There was no pyrogenic reaction following 1 gram of $\mathrm{NaCl}$, but distinct reaction following 4 grams. There was also a marked respiratory inerease and a pulse reaction. The stools increased in number and character after the ingestion of the salt solution.

The student is now given a number of exercises to work out in order to familiarize himself with the keeping of a chart. He is furnished with blank charts, pencils, etc., and an instructor to explain all the steps taken. He first plots the weight-curve. From this he constructs his energy line. By the time he has figured this line for one chart it becomes an easy task 
for him to calculate caloric requirements. Next comes the plotting of the food blocks and the stools. The class is kept together on the first chart to avoid confusion. That is, all the members of the section start each division of the chart at the same time. The chart finished, the student discusses in writing the possible causes of the weight-drop and makes a diagnosis. The completion of the chart takes almost invariably one and a half hours.

Chart 3 results from the first exercise and represents a case of simple dyspepsia from overfeeding.

Chart 4 results from the second exercise and represents a case of marasmus or the so-called decomposition. It has taken this infant eight weeks to gain 1 pound. This gain is accomplished by feeding close to the entrgy line. It illustrates low food tolerance. The primary drop in the third week is overcome by lowering the food below the energy line. A substantial gain is made with partial improvement in the stool, but when

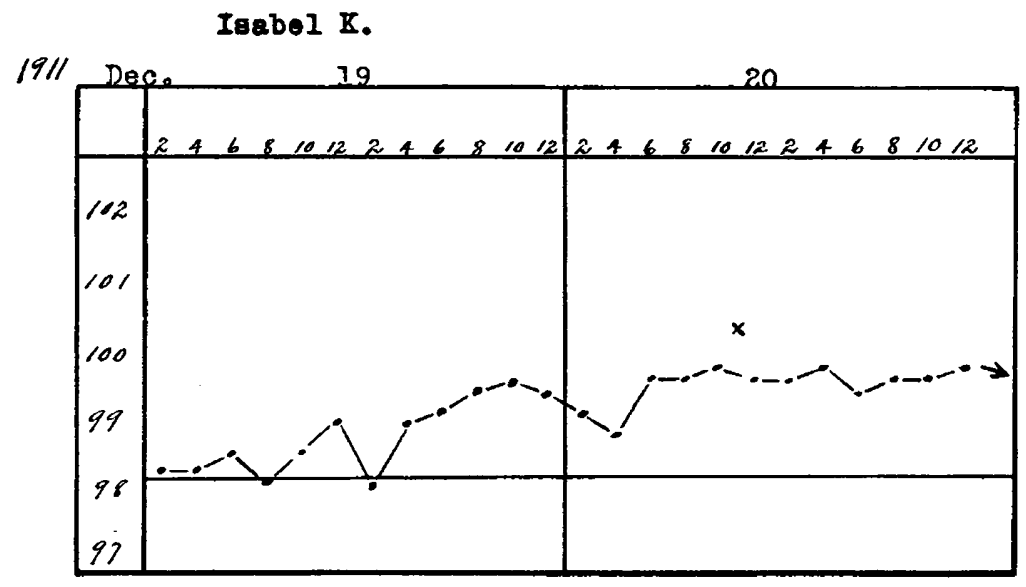

Chart 8.-Temperature curve in case of Isabel $K$. At point marked x 100 c.c. of 4 per cent. sodium bicarbonate solution were given by gavage. No pyrogenic reaction followed. The elevation of temperature was due to developing chickenpox.

the food goes 50 calories above the line a relapse takes place. The further treatment of the case is self-explanatory. These two cases are almost entirely diagrammatic and are not given out as actual cases. Further exercises are given out to be done by the student at his home.

We next take up the study of sugar tolerance. This is illustrated by Chart 5, which represents an actual study of a case by the section.

In this chart a very marked sugar (lactose) tolerance is shown. In this normal infant on the seventeenth day, after a week of stationary weight, gradually increasing percentages of sugar were added, as indicated on the chart. When $5,6, \%, 8,9,10,11$ and 12 per cent. are indicated, 
approximately $48,53,78,90,11 \%, 126,141$ and 146 grams of lactose are supplied. While there was no increase in the weight, as might have been expected for a short time, there was no marked fall, no rise in temperature, no increase in the frequency of the stools and no sugar appeared in the urine. The rise in temperature during the first week was due to circumcision.

In Chart 6 just the opposite condition is recorded. On the addition of only 50 grams of sugar, or when the sugar in the food is approximately 7 per cent., distinct symptoms of intoxication are produced. Coincident with sharp rise in temperature there are a number of abnormal stools, a decided drop in weight and the occurrence of sugar in the urine. With a reduction in the food, particularly in the sugar content, the weight ceases to drop and does not rise again until the food block nears the energy line. In this case a substantial gain is recorded with the food 80 calories below the energy line.

I have constructed this chart (5) from one of Finkelstein and Meyer's cases. ${ }^{1}$ The stools are supplied but they conform to the characteristics exhibited in mild cases of sugar intoxication and in infants fed on Eiweissmilch. In this case preceding the records here presented, during the twelfth week, while the infant was being fed buttermilk plus 5 per cent. lactose (making in all about 7.5 per cent. lactose) symptoms of dyspepsia developed with slight elevation of temperature. The improvement following the treatment with Eiweissmilch is indicated. There is first a period of seventeen days of practically stationary weight when with the addition of 20 grams Nährzucker, bringing the food line up to the energy line, the weight begins to increase until the point of intolerance is reached by the addition of 50 grams of sugar which brings the food 85 calories above the energy line. The characteristics of sugar intoxication and its treatment according to Finkelstein are indicated on the daily records which follow. With the exception of the weight-curve the chart bears little resemblance to the original from which the data was taken and converted into English terms.

This case brings up the subject of the effect of salts in infant feeding. During the period of buttermilk feeding in the case just mentioned there developed along with the dyspepsia a slight fever. It is not difficult to figure out the amount of salts the infant got during this time and one might reason that the dyspepsia and the intoxication following it some weeks later may have been due to injury of the intestinal epithelium by these salts. I therefore present some illustrations of the effect of feeding varying amounts of common salt to healthy babies. The following case will serve as an example. (Charts $\%$ and 8 .) 3 , xxi.

I. Finkelstein and Meyer: Case 24, Curve 10, Jahrb. f. Kinderh., lxxi, series 


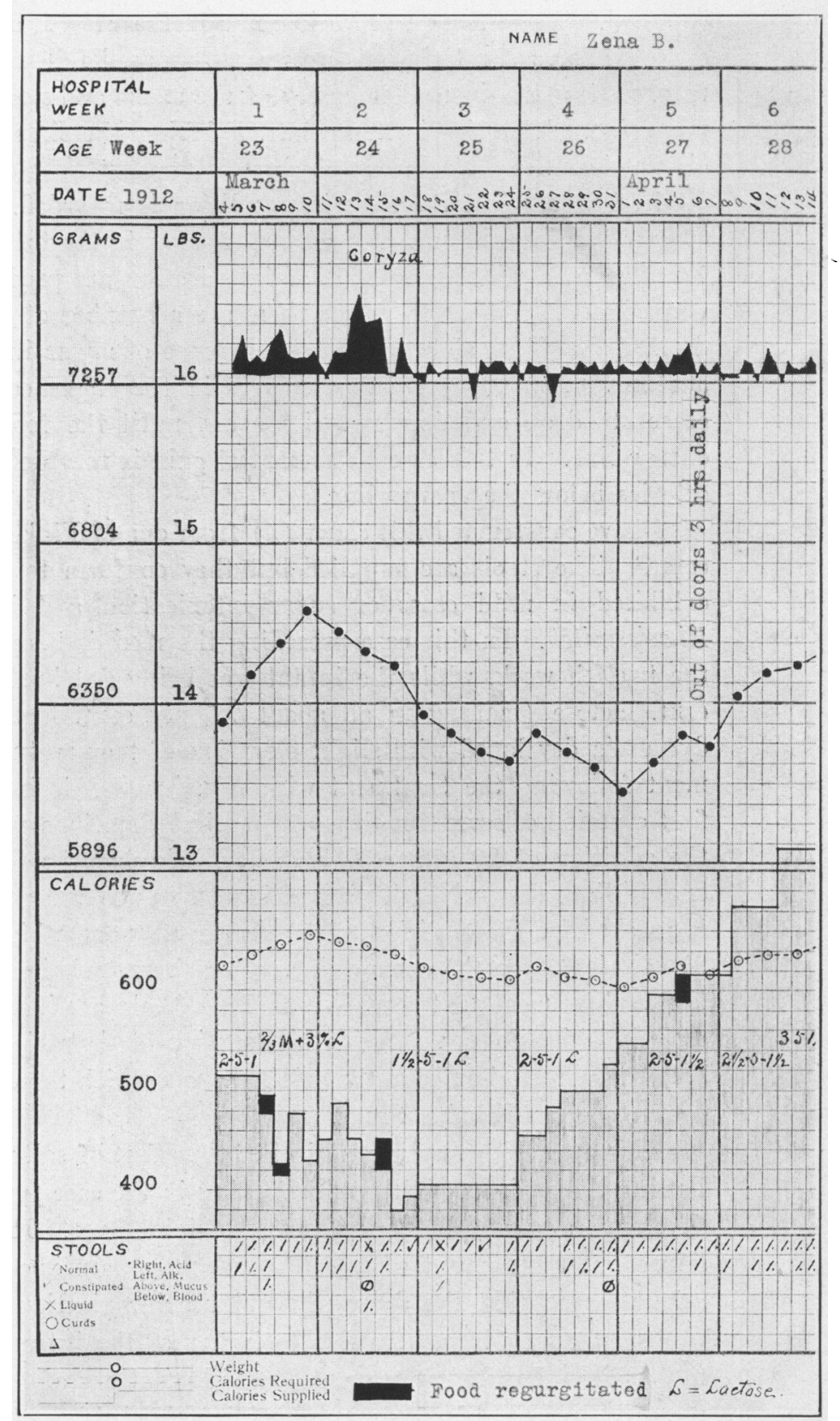

Chart 9.-A good illustration of the value of the energy lines (calories dressings for club feet. In later weighings 


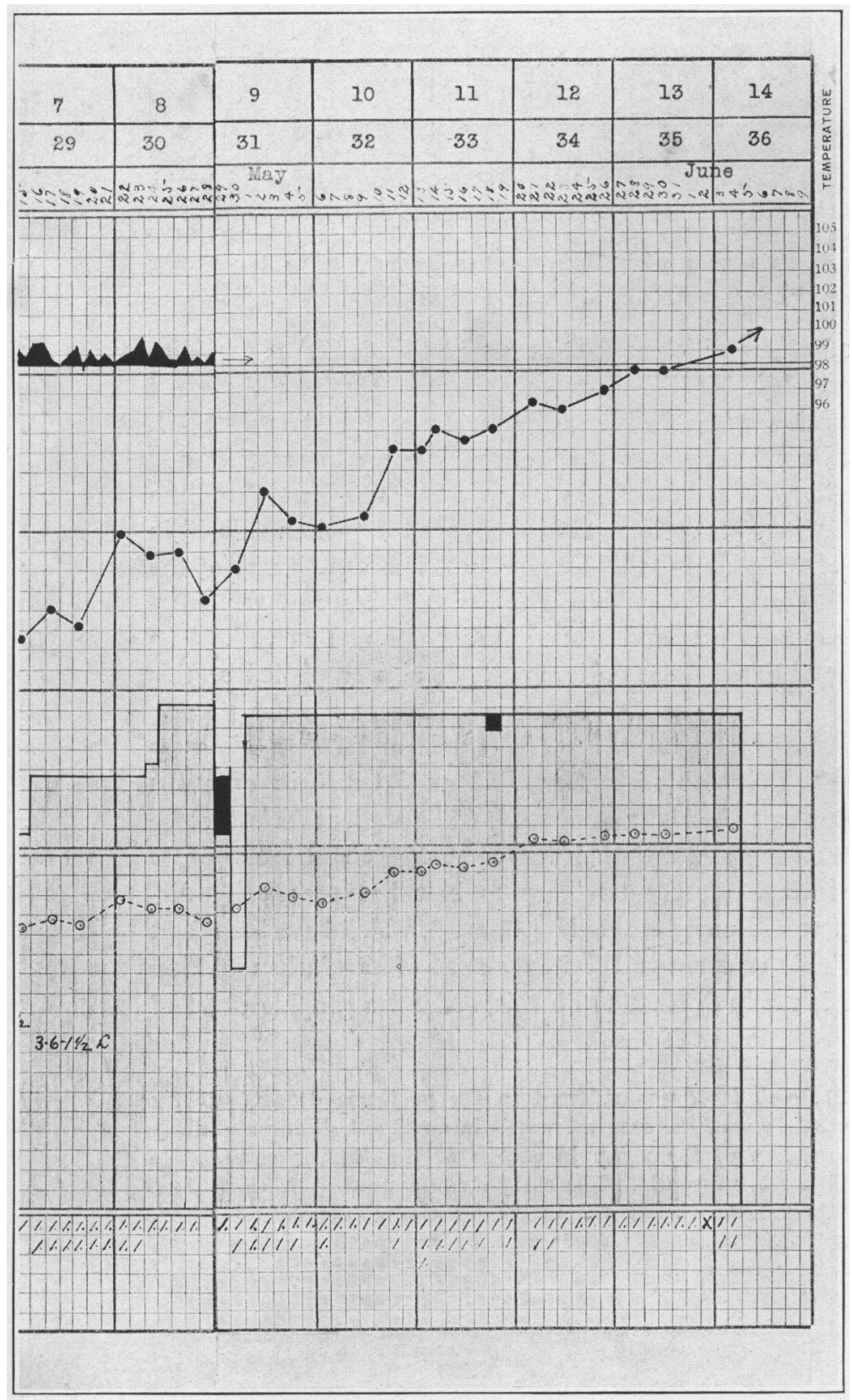

required). The gain during the first week is largely due to adjustment of plaster weight of dressings accounted for. 
Isabel K., girl baby 10 weeks old, with normal digestion and normal stools. On December 15 after a stationary temperature for eight hours and normal temperature prior to that time she is given by means of gavage in two doses an hour apart 100 grams of a 1 per cent. sodium chlorid solution, which represents 1 gram of salt. No pyrogenic reaction follows. Twenty-four hours later 100 grams of a 4 per cent. solution of sodium chlorid is given in one dose, by gavage. This represents 4 grams of salt. A distinct and marked pyrogenic reaction develops, reaching its height in six hours, declining to normal in eighteen to twenty hours. During the pyrogenic phase there is also a marked respiratory increase and pulse reaction as well as an increase in the number, and a change in the character of the stools. This phenomenon occurs with such great regularity when the proper amount of salt is given that it is very easy of demonstration before the class.

By Chart 8 , and others which are not necessary to print, the specificity of the salts is illustrated. In this same case several days later the effect of sodium combination with the non-halogen element carbon is tried. Four grams of sodium bicarbonate produces no pyrogenic reaction and at this point it is shown that in milk the halogen combinations of sodjum alone produce the pyrogenic reaction. It is therefore the sodium chlorid in the milk which is responsible for this reaction and is a constituent of the infant's food which should be considered in cases of obscure fever, diarrhea, etc., as well as the sugar and other constituents of the food. The subject of water retention by the sodium salts is also suggested at this time.

The student is now ready to go into the wards and follow his cases through. Since developing this chart method an interest in even the usually uninteresting cases has been awakened. The student feels that he is really doing something and although his visits night and morning to the ward are kept track of, the tendency to bolt has practically disappeared. I might record many charts like Chart 9 , which have been kept by the students. This case shows the importance of carefully watching hospital cases. It is really difficult to do this without a graphic chart of some kind.

Zena B. (Chart 9), club foot, was referred to the pediatric department for nourishment. She was in one of the surgical wards in another building and away from the direct observation of the nurse in charge of the feeding cases. The intern had prescribed a 2-5-1 formula. The child made a good gain in its first week in hospital. On the fourth day the intern tried a simple milk dilution, bringing the sugar up to approximately 6 per cent. by an addition of 3 per cent. lactose. About this time the child developed a coryza with slightly abnormal stools, fever, and loss of weight. The fever subsided after four days, the stools became normal after one day but the weight continued to fall. On the twenty-first day the child was brought to the Palmer ward (Ped. Dept.) and a chart was started (Chart 9 ). It will be observed that the infant was being fed far below the energy line. The food was gradually increased to the energy line and pushed above it with the results seen in the chart. The black areas represent the number of calories lost through regurgitation. The marked regurgitation on April 29

2. Dividing the dose as in the control makes no difference in the result. 
following declining weight after marked increase in the food and refusing of the total quantity made us fear the development of a dyspepsia from over-feeding; consequently on the following day the child was fed below the energy line. No bad symptoms developing, the food was again pushed to just a little below the former point, with only one day of slight regurgitation in six weeks. The temperatures are all rectal. We find that a large per cent of our babies run a temperature like the one plotted, from the third hospital week on, without any discoverable cause. It may be well to state that the salt content in our percentage formulæ is never excessive. This chart is an exact copy of the one made by the student in charge of the ease.

It is not the purpose of this paper to demonstrate any classification of the digestive disturbances of infancy. It is apparent how a chart can be used to illustrate the various causes of stationary, declining and increasing weight with their attendant symptoms and signs.

The lessons we learn from practical use of a graphic chart are that changes in weight are usually explained at a glance; that a child cannot make substantial gain on feeding below its caloric needs; that he may often make a loss by feeding far above the line and that when strict attention is given to this point, with proper adjustment of percentages and attention to fundamental principles, most cases improve. There are instances in which the very best of care and thought cannot suffice to bring about improvement. 